\title{
The Effects of Ink Presence on Mechanical, Physical, Morphological and Thermal Properties of Office and Newspaper Fiber-Polypropylene Composites
}

\author{
Emrah PEŞMAN*, Türker GÜLEÇ \\ Artvin Çoruh University, Faculty of Forestry, Wood Products Chemistry and Technology, Artvin, Turkey \\ crossref http://dx.doi.org/10.5755/j01.ms.25.2.19617
}

Received 07 December 2017; accepted 22 March 2018

\begin{abstract}
In this study the effects of ink (offset and toner) presence on the mechanical, physical, morphological and thermal properties of newspaper- and office paper fiber-plastic composites were investigated. Printed and unprinted newspaper and office paper fibers were mixed with recycled polypropylene at $50 \%$ by weight fiber loading. The samples were produced with extrusion and compression moulding. The mechanical properties, water absorption and thermal resistances of unprinted and printed newspaper- and office paper fiber-polypropylene composites were compared. In addition, samples were characterized with Fourier transform infrared spectroscopy, and scanning electron microscopy. The obtained results showed that ink presence in the fiber matrix enhanced the water resistance and mechanical properties of fiber plastic composites. Due to ink formulation and fiber characteristics, better results were obtained with printed office paper fiberplastic composites than with printed newspaper fiber-plastic composites. Scanning electron microscopy investigation also confirmed the good interaction between polypropylene and toner-printed office paper fiber. Moreover, differential scanning calorimetry measurements showed that higher crystallization $\left(\chi_{\text {cor }}\right)$ values on printed office paper- and newspaper fiber-plastic composites. This work demonstrated that undeinked waste paper fibers could be effectively used as the reinforcing filler in thermoplastic matrices.

Keywords: polymer composites, mechanical properties, compressing moulding, waste paper fibers, ink presence.
\end{abstract}

\section{INTRODUCTION}

Nowadays the use of wood or other natural fibers as a filler in plastic material has become common in the production of facade claddings, railings, decking, decorative profiles, window frames, automotive parts and furniture applications. Wood plastic composites (WPCs) or natural fiber plastic composites (FPCs) are cheaper than pure plastic and more durable than solid wood. If desired, these composite materials can be produced totally from waste sources such as waste fibers and waste thermoplastics.

Waste thermoplastics and waste paper are the two largest recyclable components of the solid waste stream. Generally, in WPC manufacturing, virgin thermoplastics including polyethylene (PE), polypropylene (PP), polyvinyl chloride (PVC) and polystyrene (PS) are widely used, while recycled and waste plastics have been used for WPCs since the 1990s [1-3].

Waste paper is generally utilized as a source of fibers in paper production. Recovered paper constituted $56 \%$ of newsprint, printing-writing paper and other paper-paper board production in 2016 [4]. However, some types of paper cannot be recycled easily due to cost of production.

Paper recycling is a very simple and economical process which usually involves stages of classification, cleaning, deinking, removing of dyes and clay and bleaching [5]. These stages and the chemicals used during the recycling process increase the cost of the end products, depending on the type of furnish. One of the factors that should be considered is the ink formulation [6], as it affects the degree of difficulty involved in the process of deinking the fiber.
During the printing process with newsprint oil-based ink and water-based ink, no significant changes occur in the chemical properties and hydrophobic characteristics of these inks. If the carrier parts of inks are hydrolyzed or eliminated, hydrophobic ink pigments can be easily separated from cellulose fibers by flotation. On the other hand, during printing with toner ink, polymerization and oxidation reactions take place. The polymerization causes a strong chemical and physical bonding with cellulose fibers and creates larger-sized particles. The oxidation creates a greater polarity at the toner particle surface [7]. These two factors make the flotation process difficult, and therefore, the use of specific aids and different processes becomes necessary. The efficiency of ink removal for toner-printed office paper can be increased by using enzymes [8], agglomeration and magnetic deinking [9] and ultrasound [10]. However, all these extra chemicals and applications increase the cost of the end product. Toner-printed office paper which cannot be recycled effectively because of deinking difficulties may be utilized in composite-plastic manufacturing without deinking.

Some research in the literature has been conducted on waste paper usage for plastic production and on paper mill waste usage as a filler or reinforcement agent in WPCs. The mechanical and thermal properties of newspaper fiberreinforced recycled polyethylene terephthalate (rPET) composites were examined by Ardekani et al. [11]. They concluded that SEBS-g-MA usage improved the impact strength but decreased the tensile and flexural strength of the composites. Furthermore, they reported that newspaper fiber addition in rPET increased the crystallinity and

\footnotetext{
*Correspondingauthor. Tel.: +90-466-2155241; fax: +90-466-2151034.
}

E-mailaddress:epn350@gmail.com (E. Pesman) 
thermal stability of the composites. The recycling of disposable cups into paper plastic composites was investigated by Mitchell et al. [12]. They improved the mechanical properties of WPCs with an addition of $40 \mathrm{wt} \%$ of disposable cup flakes in polypropylene (PP). Rodrigues Filho et al. [13] used old newspaper for cellulose acetate synthesis; however, they used only unprinted parts of these papers. Ismail and Bakar [14] studied the properties of a thermoplastic blend of paper mill sludge and PP and concluded that the properties of the paper mill sludge PP composites were similar to those of conventional WPCs. Furthermore, they improved the physical and mechanical properties of the composites with the esterification and acetylation of paper mill sludge. Soucy et al. [15] also studied the potential of paper mill sludge usage for plastic composites. Their results revealed that kraft (chemical) paper mill sludge was more suitable for plastic composite production than chemi-thermo mechanical and thermomechanical paper mill sludge. Huang et al. [16] examined the characteristics of paper mill sludge-wood-fiber-highdensity polyethylene composites. They concluded that by replacing half of the wood fiber with paper mill sludge, the bending strength and modulus of the plastic composites decreased by $16.08 \%$ and $29.91 \%$, respectively, while the impact strength increased by $11.31 \%$. Sailaja and Deephti [17] studied the mechanical and thermal properties of lowdensity polyethylene (LDPE) and esterified unbleached wood pulp. They improved the mechanical properties of composite plastic. Cellulose addition for the reinforcement of WPCs were also investigated and significant improvements were obtained [18]. Pesman and Tufan [19] studied the effects of $\mathrm{CaCO}_{3}$ coated wood free paper usage as filler on water absorption, mechanical and thermal properties of cellulose-high density polyethylene (HDPE) composites. They concluded that calcium carbonate presence had increased the water resistance of cellulose fiber-HDPE composites [19]. However, no research has been conducted on printed waste paper fiber usage and the effects of ink presence on the strength and thermal properties of WPCs.

In this study, ink factors for waste paper FPC production were investigated. Two different furnishes, newspaper and office paper, and two different printing processes, risograph and laser printing, were investigated along with the effects of ink presence on the water absorption, tensile properties and thermal properties of waste paper plastic composites.

\section{MATERIALS AND METHODS}

\subsection{Materials}

The raw materials used in this study consisted of printed and unprinted office and newspaper as fillers and waste polypropylene (rPP) as the polymer matrix. The newspaper (mechanical pulp paper) was printed on both sides using a Rex-Rotary DX3443 risograph machine. The office paper (chemical pulp paper) was printed on both sides using a Brother DCP-7055 laser printer.

\subsection{Fiber preparation}

First, office and newspaper samples were divided into $3 \times 3 \mathrm{~cm}$ pieces then repulped in a Micro-Maelström laboratory pulper. Pulping was carried out at 45 to $50{ }^{\circ} \mathrm{C}$ for 10 min without chemical addition. After the pulping, fibers dried to oven dry at $103 \pm 2{ }^{\circ} \mathrm{C}$ for 24 hours. Then, dried fibers were granulated into flour form using a Willey mill.

\subsection{Composite manufacturing and compounding}

The experimental design of the study is presented in Table 1. Two sets of experiments were carried out. One was designed to investigate the effect of the furnish grade of newspaper (mechanical pulp) and office paper (chemical pulp) fiber, while the other was designed to show the effect of ink presence in the polymer-filler matrix. During the manufacturing process, depending on the formulation, granulated recycled paper plastic pulp fibers were mixed without addition of a coupling agent in a high-intensity mixer to produce a homogeneous blend. This blend was then compounded in a laboratory scale co-rotating single-screw extruder (RONDOL 3212). The four-barrel temperature zones of the extruder were controlled at 175 and $190{ }^{\circ} \mathrm{C}$. The extruded samples were collected, cooled, and granulated into pellets. Finally, the pellets were compressed for $3 \mathrm{~min}$ at $170{ }^{\circ} \mathrm{C}$ into $5 \times 150 \times 160 \mathrm{~mm}$ composites. The reason for choosing the ratio of filler to $50 \%$ is to see the effect of the presence of ink on the fiber composites more clearly.

Table 1. Experimental design of the study

\begin{tabular}{|c|c|c|l|}
\hline $\begin{array}{c}\text { Sample } \\
\text { code }\end{array}$ & $\begin{array}{c}\text { rPP, } \\
\%\end{array}$ & Filler, $\%$ & Filler Grade \\
\hline A & 50 & 50 & Unprinted office paper fiber \\
\hline B & 50 & 50 & $\begin{array}{l}\text { Toner ink printed office paper } \\
\text { fiber }\end{array}$ \\
\hline C & 50 & 50 & Unprinted newspaper fiber \\
\hline D & 50 & 50 & $\begin{array}{l}\text { Oil based black ink printed } \\
\text { newspaper fiber }\end{array}$ \\
\hline
\end{tabular}

\subsection{Dimensional stability}

The water absorption (WA) tests were carried out according to ASTM D 570. For the WA test, ten $50(\mathrm{~L}) \times 50(\mathrm{~W}) \times 5(\mathrm{~T}) \mathrm{mm}$ specimens from each group were used. The conditioned specimens were completely immersed for $2,24,48,96,168,336,504$ and $672 \mathrm{~h}$ in a container of water at $23 \pm 2{ }^{\circ} \mathrm{C}$. At the end of each immersion time, the specimens were removed from the water, dried using a clean dry cloth and immediately weighed to the nearest $0.001 \mathrm{~mm}$. The water absorption $(W A)$ and thickness swelling $(T S)$ values were calculated using the following equations:

$W A(\%)=100\left[\left(W_{2}-W_{1}\right) / W_{1}\right]$

where $W A, W_{1}$ and $W_{2}$ are the water absorption (\%), weight of the dry specimen $(\mathrm{g})$ and weight of the wet specimen $(\mathrm{g})$, respectively.

$T S(\%)=100\left[\left(T_{2}-T_{1}\right) / T_{1}\right]$ 
where $T S, T_{1}$ and $T_{2}$ are the thickness swelling (\%), thickness of the dry specimen (mm) and thickness of the wet specimen $(\mathrm{mm})$, respectively.

\subsection{Mechanical properties}

Testing of the produced composites was conducted in a climate-controlled testing laboratory. Flexural and tensile properties of all waste paper FPCs were determined. The flexural tests were conducted in accordance with ASTM D 790. Test samples were cut to the dimensions of $150(\mathrm{~L}) \times 13(\mathrm{~W}) \times 5(\mathrm{~T}) \mathrm{mm}$. The span length of each specimen was $80 \mathrm{~mm}$. Samples were tested on a Zwick $50 \mathrm{KN}$. The rate of crosshead motion was $2.0 \mathrm{~mm} / \mathrm{min}$, which was calculated according to ASTM D 790 standard. The tensile tests were conducted according to ASTM D 638. Test samples were cut to the dimensions of $165(\mathrm{~L}) \times 13(\mathrm{~W}) \times 5(\mathrm{~T}) \mathrm{mm}$. Tests were performed at a rate of $5.0 \mathrm{~mm} / \mathrm{min}$. Seven specimens of each formulation were tested.

\subsection{Thermogravimetric (TGA) and differential scanning calorimetry (DSC) analyses}

A Perkin Elmer TGA-6000 thermal analyzer was used for thermogravimetric analysis (TGA) of the samples. The heating rate was $10^{\circ} \mathrm{C} / \mathrm{min}$ under nitrogen at a flow rate of $20 \mathrm{~mL} / \mathrm{min}$. Tests were performed at temperatures ranging from room temperature to $600{ }^{\circ} \mathrm{C}$. TGA measurements were performed with $17-20 \mathrm{mg}$ powdered samples.

Thermal analysis of the WPC samples was carried out on a differential scanning calorimeter (Perkin Elmer Instruments DSC 8000). All DSC measurements were performed with 5-6 mg powdered samples under a nitrogen atmosphere at a flow rate of $20 \mathrm{~mL} / \mathrm{min}$. The values of $\Delta H_{\mathrm{m}}$ were used to estimate $\chi(\%)$, which was adjusted for each sample in $\chi$ cor $(\%)$ based on the percentage of polypropylene (PP) in the composite. The degree of crystallinity $\left(\chi_{\text {cor }}\right)$ of the PP component was determined using the following equation [20,2 1]:

$X \mathrm{c}=\left(\Delta H_{\mathrm{m}} / \Delta H_{0}\right) \cdot(100 / W) \cdot 100 \%$,

where $\Delta H_{\mathrm{m}}$ and $\Delta H_{0}$ are the heat of fusion of the composites and $100 \%$ crystalline polypropylene, respectively, and MF is the filler proportion. In this calculation, $\Delta H_{0}$ was taken to be $207(\mathrm{~J} / \mathrm{g})$ [22].

\subsection{Scanning electron microscope (SEM) imaging}

A Carls Zeiss Evo LS-10 scanning electron microscope was used to study the fractured surface of the samples. To prepare the fractured surfaces, the samples were first dipped into liquid nitrogen and snapped in half. The samples were then mounted on the sample stub and sputtered with gold.

\subsection{Fourier transform infrared (FTIR) spectroscopy analysis}

The Shimadzu IR Prestige-21 FTIR equipped with ATR was used to study the characterization of the fiber-PP composites. The spectra were recorded between 600 and $4000 \mathrm{~cm}^{-1}$, with 16 scans per experiment and a resolution of $8 \mathrm{~cm}^{-1}$. All the spectra for each group were transformed into absorbance spectra averaged before baseline correction and normalization.

\subsection{Statistical analysis}

All results (mechanical and decay) were evaluated with analysis of variance (ANOVA). All means were compared using the Duncan multiple comparison test (95\% confidence interval) using a SPSS statistical program (SPSS 19. 2010).

\section{RESULTS AND DISCUSSION}

Fig. 1 shows the water absorption of the samples. The water absorption of the unprinted office paper FPCs increased to $9.84 \%$ after $504 \mathrm{~h}$ in water. However, the toner-printed office paper FPCs increased to $7.96 \%$ for the same holding period in water. The presence of toner ink in the plastic composites affected the water resistance of the samples positively. On the other hand, the water absorption of unprinted and oil-based ink printed newspaper FPCs had increased to $12.02 \%$ and $11.77 \%$, respectively, after $504 \mathrm{~h}$ in water. Because of the high hemicellulose content, i.e. more amorphous parts, the newspaper (mechanical pulp) fibers absorbed more water than the office paper (chemical pulp) fibers. Similar results were observed by Liu et al. [23] in their study on wood, cellulose and lignin flours as fillers in plastic composites. They concluded that the water uptake values of the cellulose fiber were lower than those of wood fiber as a result of high crystallinity. The ink presence in newspaper FPCs did not significantly affect the water absorption, whereas toner ink presence significantly affected the water absorption of office paper FPCs. The reason for this may be that the toner ink acts as a coupling agent due to high polarity or the filling of the cavity of the plastic composite matrix.

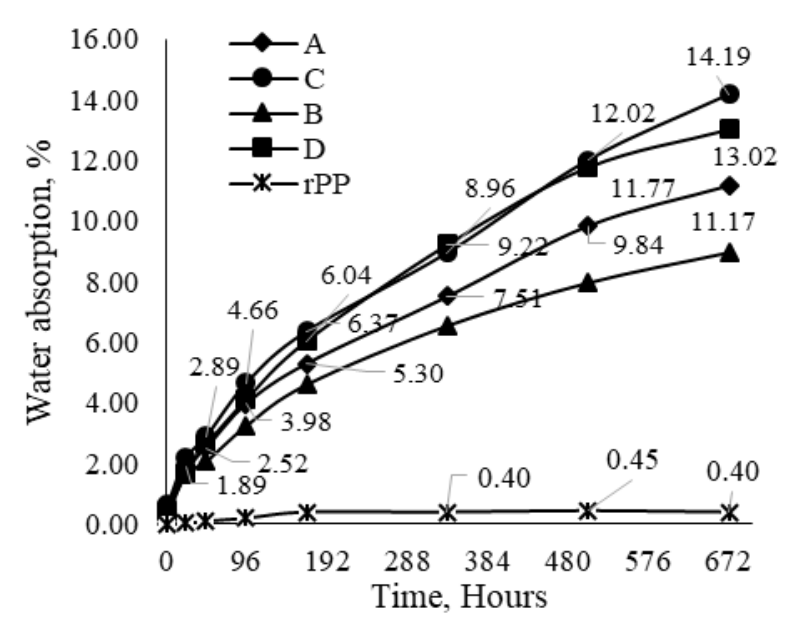

Fig. 1. Water absorption of fiber-rPP composites

The flexural and tensile property values of waste paper FPCs are shown in Table 2. Composites manufactured from printed office paper fiber ensured higher flexural strength and modulus than composites from unprinted office paper fiber. The flexural strength and modulus values of the composites with unprinted office paper fiber were 24.2 $\mathrm{MPa}$ and $2.3 \mathrm{GPa}$, respectively, while the flexural strength and modulus values of composites with printed office paper fiber were 26.9 MPa and 2.4 GPa, respectively. The flexural strength and modulus values of the composites with unprinted newspaper fiber were $21.3 \mathrm{MPa}$ and $2.3 \mathrm{GPa}$, 
respectively, whereas the flexural strength and modulus values of the composites with printed newspaper fiber were 25.1 MPa and 2.5 GPa respectively. The same trend was observed in the tensile properties. Statistically, the flexural modulus and elongation at break (\%) values were not significantly different. Significant improvement of flexural strength and tensile property values was observed in printed office paper and newspaper FPCs. These values were significantly different at $5 \%$.

Table 2. Mechanical properties of FPCs

\begin{tabular}{|c|c|c|c|c|c|}
\hline $\begin{array}{c}\text { Sample } \\
\text { code }\end{array}$ & $\begin{array}{c}\text { Flexural } \\
\text { strength, } \\
\mathrm{MPa}\end{array}$ & $\begin{array}{c}\text { Flexural } \\
\text { modulus, } \\
\mathrm{GPa}\end{array}$ & $\begin{array}{c}\text { Tensile } \\
\text { strength, } \\
\mathrm{MPa}\end{array}$ & $\begin{array}{c}\text { Tensile } \\
\text { modulus, } \\
\mathrm{GPa}\end{array}$ & $\begin{array}{c}\text { Elongation at } \\
\text { break, \% }\end{array}$ \\
\hline $\mathrm{rPP}$ & 28.3 & 1.1 & 17.2 & 0.7 & 3.8 \\
\hline $\mathrm{A}$ & $24.2 \mathrm{~b}$ & $2.3 \mathrm{a}$ & $12.6 \mathrm{~b}$ & $1.4 \mathrm{~b}$ & $1.9 \mathrm{a}$ \\
\hline $\mathrm{B}$ & $26.9 \mathrm{c}$ & $2.4 \mathrm{a}$ & $15.6 \mathrm{c}$ & $1.7 \mathrm{bc}$ & $2.1 \mathrm{a}$ \\
\hline $\mathrm{C}$ & $21.3 \mathrm{a}$ & $2.3 \mathrm{a}$ & $10.8 \mathrm{a}$ & $1.3 \mathrm{a}$ & $1.7 \mathrm{a}$ \\
\hline $\mathrm{D}$ & $25.1 \mathrm{bc}$ & $2.5 \mathrm{a}$ & $14.9 \mathrm{c}$ & $1.8 \mathrm{c}$ & $1.8 \mathrm{a}$ \\
\hline
\end{tabular}

This improvement may be explained by the nature of the toner ink. In most laser imaging systems, toners are dry powders made up of a blend of various types of thermoplastic polymers or copolymers that may be pigmented with iron oxides $(\approx 35 \mathrm{wt} . \%)$, colored pigments, carbon black and dyes. Example of copolymers includes styrene-butadien, styrene-methacrylate, styrenebutylacrylate or polyacrylates [24]. The polymerization of toners during the printing process results in the formation of larger particles [25]. This process might lead to chemical bonding between the cellulose fiber and the new larger ink particles and to physical entrapment of the cellulose fiber within the large ink particles. Of course, the oxidation creates a greater polarity at the ink surface [7]. This situation has a negative impact on the recycling and deinking of waste office paper fibers, but it may be advantageous in plastic composite manufacturing. In general, the PE and PP, which are widely used in WPC manufacturing, have low polarity and low surface free energy, contributing to a highly hydrophobic nature. Surface modification and functionalization approaches are used to modify the surface properties of these polymers without affecting their bulk properties [1]. During modification, some polar groups are induced in the polymer, and the wettability and hydrophilicity of the polymer increases [26]. In this study, the toner ink content may have increased the polarity of the waste PP. Kazemi-Najafi et al. [1] showed that oxidized PP was more effective than maleic anhydride-grafted polypropylene as a coupling agent for improving the physical and mechanical properties of wood-floor-PP composites. A blend of various thermoplastics and copolymers in the toner may also have been a better fit with polypropylene than the natural fiber. Consequently, the toner-printed fiber-polypropylene composites had better mechanical and physical results than the unprinted fiberpolypropylene composites.

Because of the higher cellulose content, i.e. more crystalline fibers, waste office paper-based composites had better flexural strength and modulus than newspaper fiberbased composites. Ou et al. [27] studied the wood cell wall composition on the rheological properties of wood particle/HDPE composite blends. They concluded that, due to efficient removal of amorphous compositions, the rheological behavior ranked as follows: alpha cellulose/HDPE $>$ hemicellulose removed wood particle/HDPE $>$ wood fiber/HDPE $>$ holocellulose/HDPE.

In Fig. 2 and Fig. 3, SEM images of the waste paper FPCs are shown. Fig. 2 show the poor dispersion of the filler in the polymer matrix (A and C). Unprinted paper fiber could not couple well with the plastic. Fig. 3 shows good surface adhesion results (B and D). This indicates good encapsulation between the waste paper fiber and the polymer matrix. Some waste paper fibers were embedded in the polymer matrix. The ink-printed paper fiber exhibited relatively better coupling with the plastic than the unprinted paper fiber.

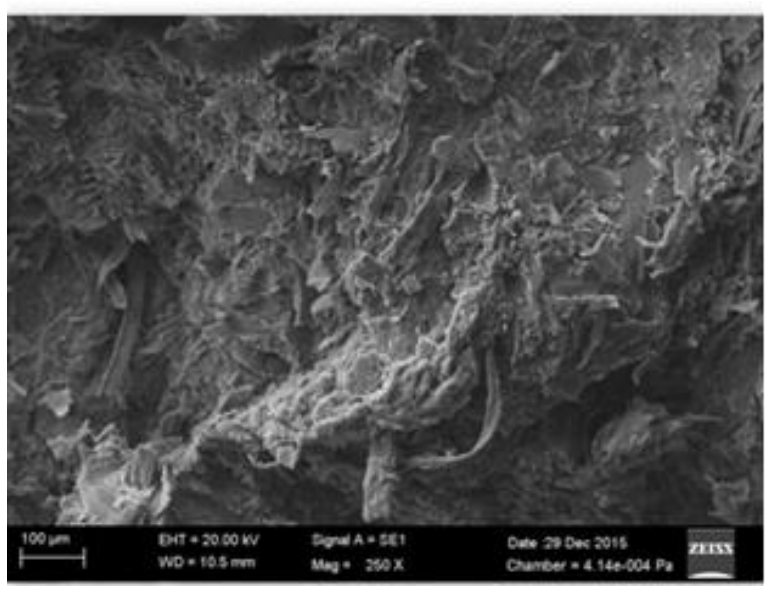

a

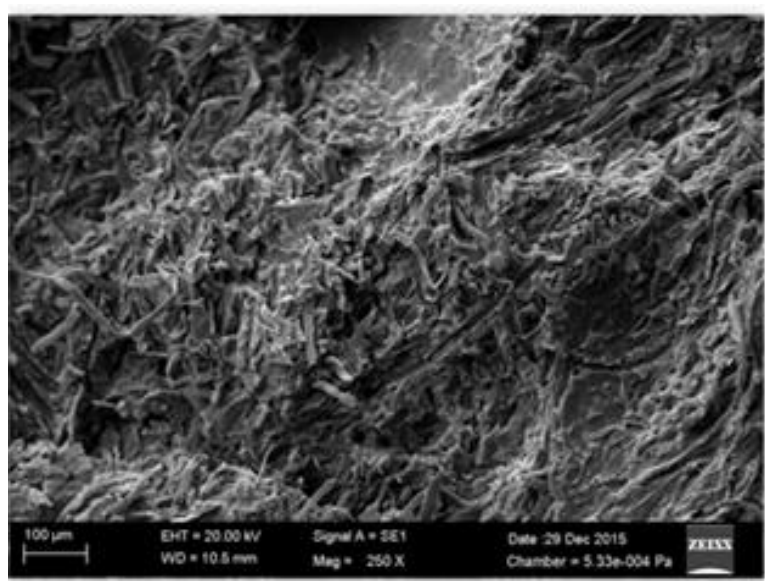

b

Fig. 2. SEM images of unprinted office and newspaper fiber filled FPCs: a-C (unprinted newspaper FPC); $\mathrm{b}-\mathrm{A}$ (unprinted office paper FPC)

Thermogravimetric analysis involves the measurement of the weight loss or gain of a material as a function of time and temperature, and it has proven to be an effective method for evaluating the thermal stability of polymers. The TGA and derivative thermogravimetric curves of recycled PP, unprinted office paper FPC (A), toner (laser) printed office paper FPC (B), unprinted newspaper FPC (C), and oil-based ink-printed newspaper FPCs (D) are shown in Fig. 4 and Fig. 5, respectively. The decomposition profiles of the composites are characterized by two peaks. The first one, which corresponds to the degradation (TGA) of fibers (hemicelluloses, cellulose, lignin for newspaper / cellulose 
for office paper), started at about $336,339,338$, and $291{ }^{\circ} \mathrm{C}$ and the maximum weight loss rates occurred at 377,383 , 391 , and $409{ }^{\circ} \mathrm{C}$ for the composites with unprinted office paper fiber, printed office paper fiber, unprinted newspaper fiber, and printed newspaper fiber, respectively.

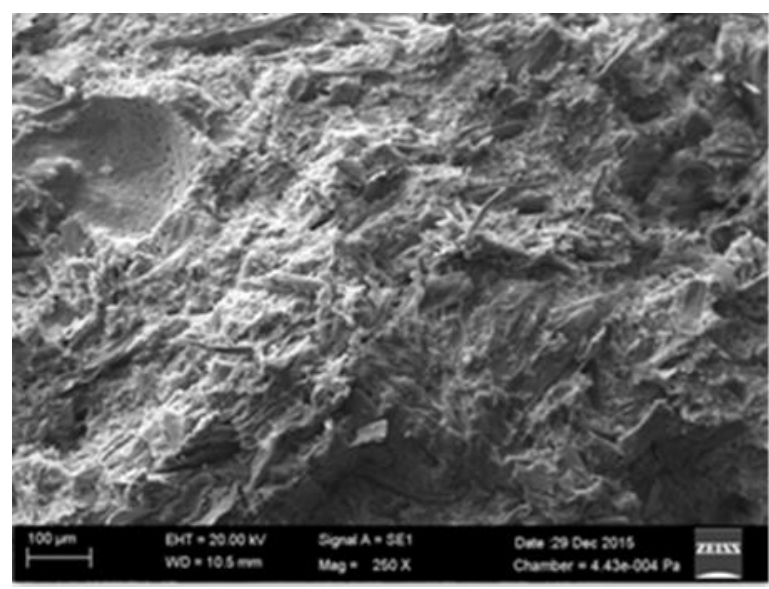

a

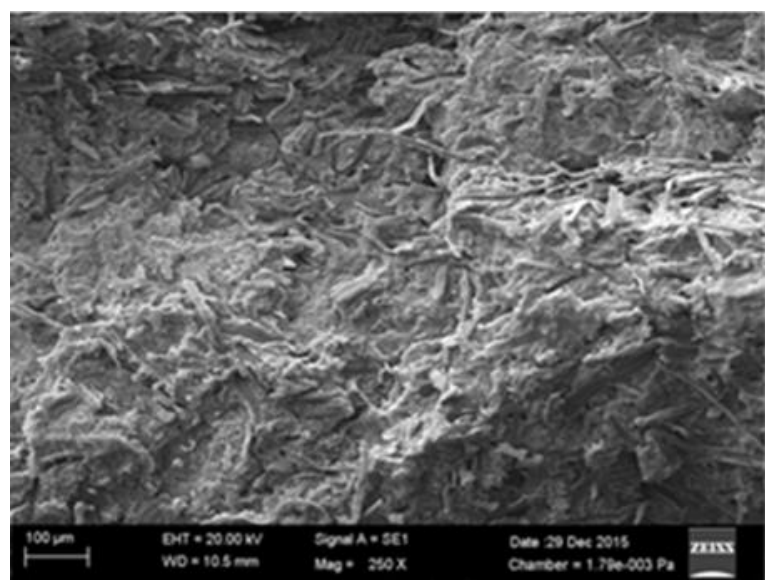

$\mathrm{b}$

Fig. 3. SEM images of printed office and newspaper fiber filled FPCs: $a-D$ (printed newspaper FPC); $b-B$ (printed office paper FPC)

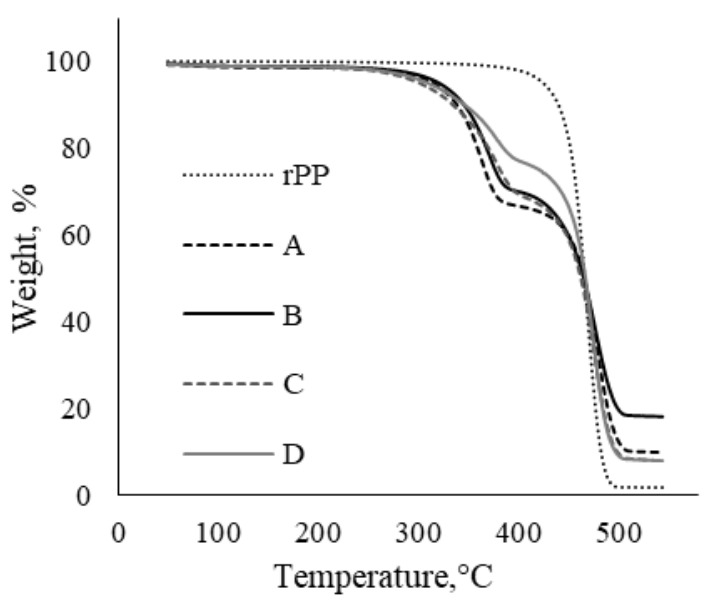

Fig. 4. TGA curves of FPCs

Office paper fiber (cellulose) composites had lower decomposition temperatures than newspaper fiber (cellulose, hemicelluloses and lignin together) composites. Toner-printed office paper fiber composites had better thermal stability than unprinted office paper fiber composites.

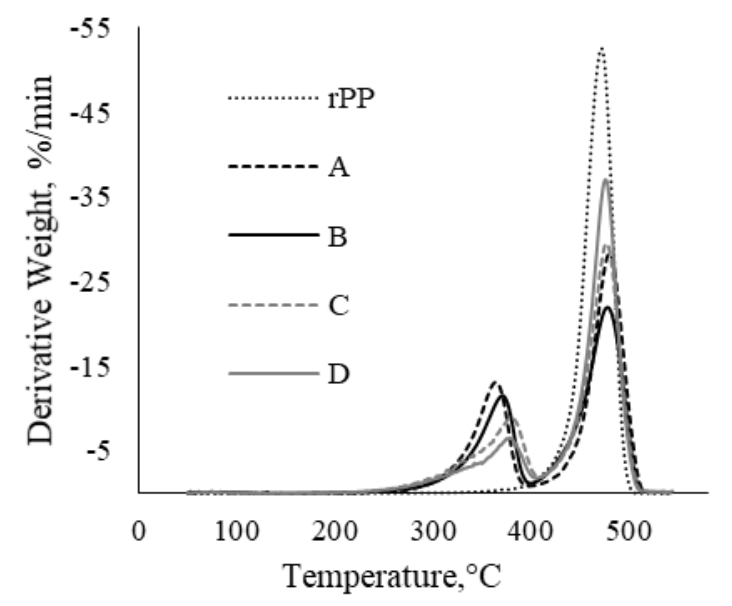

Fig. 5. Derivatives of TGA curves

In the second step, thermal degradation occurred at $458-496, \quad 450-495, \quad 457-491, \quad$ and $456-489{ }^{\circ} \mathrm{C}$ for composites containing $50 \mathrm{wt} . \%$ unprinted office paper fiber, $50 \mathrm{wt} . \%$ toner-printed office paper fiber, 50 wt. $\%$ unprinted newspaper fiber, and 50 wt.\% oil-based ink-printed newspaper fiber, respectively. The physical properties of the plastic composites can be significantly affected by the crystallization characteristics of polypropylene. Table 3 summarizes the results of DSC measurement. The crystallization ( $\chi$ cor) of printed paper plastic composites was higher than that of unprinted fiber plastic composites.

Table 3. Thermal and crystalline properties of samples

\begin{tabular}{|l|c|c|c|c|c|}
\hline Sample code & rPP & A & B & C & D \\
\hline$T_{\text {cold }}, \mathrm{C}^{\circ}$ & 123.15 & 123.47 & 123.06 & 123.26 & 123.21 \\
\hline $\begin{array}{l}\text { Peak height } \\
\text { cold, mWd }\end{array}$ & -30.71 & -16.21 & -19.18 & -18.30 & -22.57 \\
\hline$\Delta H_{\text {cold }}, \mathrm{J} / \mathrm{g}$ & -68.86 & -35.90 & -40.08 & -40.19 & -51.74 \\
\hline$T_{\text {melt }}, \mathrm{C}^{\circ}$ & 167.93 & 164.36 & 163.88 & 164.02 & 164.38 \\
\hline $\begin{array}{l}\text { Peak height } \\
\text { melt, } \mathrm{mW}\end{array}$ & 12.93 & 7.57 & 9.05 & 8.45 & 9.14 \\
\hline$\Delta H_{\text {melt }}, \mathrm{J} / \mathrm{g}$ & 58.97 & 28.30 & 34.05 & 35.61 & 40.09 \\
\hline$X_{\text {corr }} \%$ & 28.49 & 24.86 & 29.91 & 31.28 & 35.21 \\
\hline
\end{tabular}

The FTIR-ATR spectra of unprinted (A) and printed (B) office paper FPCs, unprinted (C) and printed (D) newspaper FPCs are shown in Fig. 6. Polypropylene spectrum peaks are very dominant in the composite plastic spectrum, but peaks of C-O in cellulose and hemicellulose can be seen in both office and mechanical paper plastic composite spectra at the $1040 \mathrm{~cm}^{-1}$ wavelength (A, B, C, D). The peaks of $\mathrm{C}-\mathrm{O}$ in the $\mathrm{O}=\mathrm{C}-\mathrm{O}$ groups (carbohydrates) can be seen in the office paper fiber plastic composite spectra at the 1253 $\mathrm{cm}^{-1}$ wavelength $(\mathrm{A}, \mathrm{B})$. Due to the high lignin content, the newspaper fiber plastic composite spectra (C, D) also showed peaks of aromatic skeletal vibration in lignin at $1505 \mathrm{~cm}^{-1}$ and $1593 \mathrm{~cm}^{-1}$. Additionally, the $\mathrm{C}=\mathrm{O}$ stretch in xylans can be seen at $1732 \mathrm{~cm}^{-1}$. 


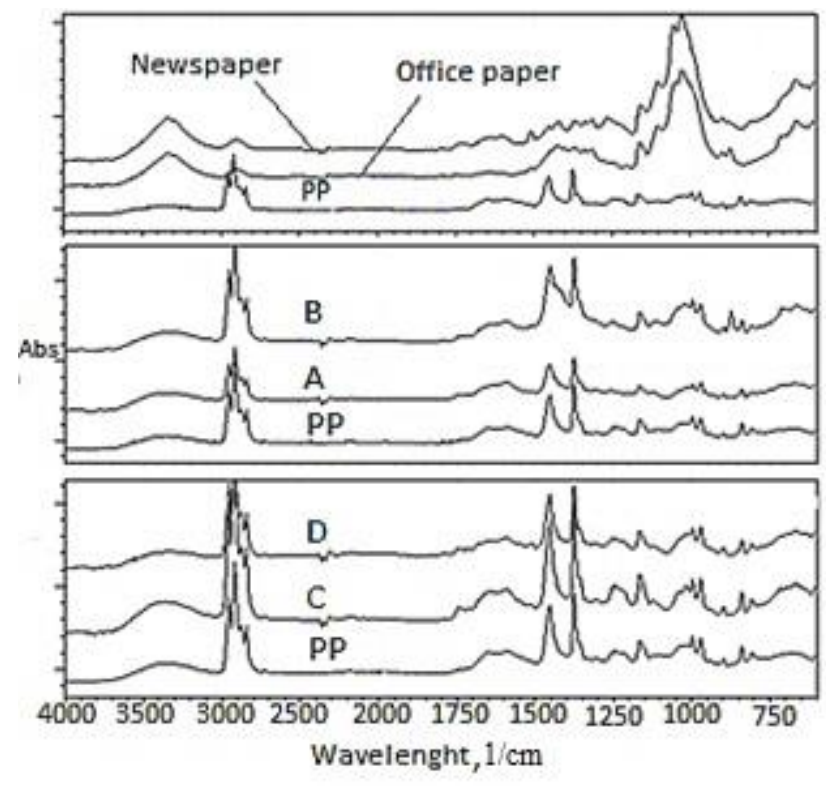

Fig. 6. FTIR-ATR spectra of fillers and FPCs

\section{CONCLUSION}

In this study, the suitability of ink-printed waste paper fiber as a filler for plastic composites was investigated. Results indicated that toner ink-printed fiber plastic composites demonstrated much better strength properties, water absorption resistance, and coupling with plastic than unprinted fiber plastic composites. The iron oxide content of toner ink on the fiber surface increased the polarity of the waste polypropylene and caused it to provide better compatibility between the plastic and the fibers. Moreover, the blend of various thermoplastics and copolymers in the toner may also have been a better fit with polypropylene than the natural fibers. In plastic composites, offset-printed fibers gave similar results to unprinted waste paper fibers. These findings indicate that toner-printed office paper which cannot be recycled because of deinking difficulties can be utilized effectively in the composite plastic manufacturing industries without deinking.

\section{REFERENCES}

1. Najafi, S.K. Use of Recycled Plastics in Wood Plastic Composites Waste Management

2013: pp. $1898-1905$.

https://doi.org/10.1016/j.wasman.2013.05.017

2. Alcock, B., Cabrer, N.O., Barkoula, N.M., Peijs, T. The Effect of Processing Conditions on the Mechanical Properties and Thermal Stability of Highly Oriented PP Tapes European Polymer Journal 45 2009: pp. $2878-2894$.

https://doi.org/10.1016/j.eurpolymj.2009.06.025

3. Joseph, K., Varghese, S., Kalaprasad, G., Thomas, S., Prasannakumari, L., Koshy, P., Pavithran, C. Influence of Interfacial Adhesion on the Mechanical Properties and Fracture Behaviour of Short Sisal Fiber Reinforced Polymer Composites European Polymer Journal 32 1996: pp. $1243-1250$.

https://doi.org/10.1016/S0014-3057(96)00051-1

4. Faostat. World's Total Paper and Paperboard - Recycled Paper Production Values, Food and Agriculture Organization of the United Nations Statistics Division.
http://faostat3.fao.org/browse/F/*/E， (2018, accessed 24.02.2018).

5. McKinney, R.W.J. Technology of Paper Recycling. Glasgow: Blackie Academic \& Professional, 1987.

6. Shrinath, A., Szewezak, J.T., Bowen, I.J. A Review of Ink Removal Techniques in Current Deinking Technology Tappi Journal 74 (4) 1991: pp. 85-93.

7. Nie, X., Miller, J.D., Yeboah, Y.D. The Effect of Ink Types and Printing Process on Flotation Deinking Efficiency of Wastepaper Recycling Environmental Engineering and Policy 1 1998: pp. 47-58. https://doi.org/10.1007/s100220050005

8. Prasad, D.Y. Enzymatic Deinking of Laser and Xerographic Office Wastes Appita Journal 46 (4) 1993: pp. 289-292.

9. Azevedo, M.A.D., Miller, J.D. Aglomeration and Magnetic Deinking for Office Paper Tappi Journal 83 (3) 2000: pp. 66-72.

10. Norman, J.C., Sell, N.C., Panelski, M. Deinking Laserprint Paper Using Ultrasound Tappi Journal 77 (3) 1994: pp. $151-158$

11. Ardekani, S.M., Dehghani, A., Al-Maadeed, M.A., Wahit, M.U., Hassan, A. Mechanical and Thermal Properties of Recycled Poly(Ethylene terephthalate) Reinforced Newspaper Fiber Composites Fibers and Polymers 15 (7) 2014: pp. 1531-1538. https://doi.org/10.1007/s12221-014-1531-y

12. Mitchell, J., Vandeperre, L., Dvorak, R., Kosior, E., Tarverdi, K., Cheeseman, C. Recycling Disposable Cups into Paper Plastic Composites Waste Management 34 (11) 2014: pp. $2113-2119$. https://doi.org/10.1016/j.wasman.2014.05.020

13. Filho, G.R, Monterio, D.S., Meireles, C.S., Assunção, R.M.N., Cerqueira, D.A., Barud, H.S., Ribeiro, S.J.L., Messadeq, Y. Synthesis and Characterization of Cellulose Acetate Produced from Recycled Newspaper Carbohydrate Polymers 73 2008: pp. $74-82$. https://doi.org/10.1016/j.carbpol.2007.11.010

14. Ismail, S.H., Bakar, A.A. Effects of Chemical Modification of Paper Sludge Filled Polypropylene (PP)/Ethylene propylene diene terpolymer (EPDM) Composites Journal of Reinforced Plastics and Composites 25 (1) 2006: pp. $43-58$. https://doi.org/10.1177/0731684406055454

15. Souchy, J., Koubaa, A., Migneault, S., Riedl, B. The Potential of Paper Mill Sludge for Wood-Plastic Composites Industrial Crops and Products 54 2014: pp. 248-256. https://doi.org/10.1016/j.indcrop.2014.01.013

16. Huangh, H.B., Du, H.H., Wang, W.H., Shi, J.Y. Characteristics of Paper Mill Sludge-Wood Fiber-HighDensity Polyethylene Composites Polymer Composites 33 (9) 2012: pp. $1628-1634$. https://doi.org/10.1002/pc.22287

17. Sailaja, R.R.N., Deepthi, M.V. Mechanical and Thermal Properties of Compatibilized Composites of LDPE and Esterified Unbleached Wood Pulp Polymer Composites 32 (2) 2011: pp. 199-209. https://doi.org/10.1002/pc.21033

18. Bullions, T.A., Hoffman, D., Gillespie, R.A., PriceO'Brien, J., Loos, A.C. Contributions of Feather Fibers and Various Cellulose Fibers to the Mechanical Properties of Polypropylene Matrix Composites Composites Science and Technology 66 (1) 2006: pp. 102-114. 
https://doi.org/10.1016/j.compscitech.2005.03.017

19. Peşman, E., Tufan, M. The Effects of $\mathrm{CaCO}_{3}$ Coated Wood Free Paper Usage as Filler on Water Absorption, Mechanical and Thermal Properties of Cellulose-High Density Polyethylene Composites Material Science (Medziagotyra) 22 (4) 2016: pp. 530-535. http://dx.doi.org/10.5755/j01.ms.22.4.14222

20. Mandelkern, L. Crystallization of Polymer. Series in Advanced Chemistry. New York: McGraw-Hill, 1964.

21. Norma, F.M., Villar, M.A. Thermal and Mechanical Characterization of Linear Low-Density Polyethylene/Wood Flour Composites Journal of Applied Polymer Science 90 (10) 2003: pp. 2775-2784. https://doi.org/10.1002/app.12934

22. Wunderlich, B. Thermal Analysis. New York: Academic Press, 1990: pp. 417-431.

23. Liu, R., Peng, Y., Cao, J., Cao, J., Chen, Y. Comparison on Properties of Lignocellosic Flour/Polymer Composites by Using Wood, Cellulose, and Lignin Flours as Fillers Composites Science and Technology 103 2014: pp. 1-7. https://doi.org/10.1016/j.compscitech.2014.08.005

24. Seldin, I. Xerographic Copy Recycling In: 1985 TAPPI Pulping Conference Proceedings 1985: pp. 303-310.

25. Pan, R., Paulsen, F.G., Kocer, H., Nerez, R., Johnson, D.A., Bousfield, D.W., Thompson, E.V. A Global Model for Predicting Flotation Efficiencies Proceedings 1994 TAPPI Recycling Symposium 1994: pp. 291

26. Cho, J.D., Kim, S.G., Hong, J.W. Surface Modification of Polypropylene Sheets by UV-Radiation Grafting Polymerization Journal of Applied Polymer Science 99 (4) 2006: pp. $1446-1461$. https://doi.org/10.1002/app.22631

27. Ou, R., Xie, Y., Wolcott, M.P., Sui, S., Wang, Q. Morphology, Mechanical Properties, and Dimensional Stability of Wood Particle/High Density Polyethylene Composites: Effect of Removal of Wood Cell Wall Composition Materials \& Desing 58 2014: pp. 339-345

https://doi.org/10.1016/j.matdes.2014.02.018 